\title{
A new autosomal recessive anomaly mimicking Fanconi's anaemia phenotype
}

\author{
R D G Milner, K A Khallouf, R Gibson, A Hajianpour, C G Mathew
} Dubai

K A Khallouf

Department of

Medical Genetics,

Guy's Hospital,

London

R Gibson

A Hajianpour

C G Mathew

Correspondence to: Professor Milner.

Accepted 2 August 1992

(Arch Dis Child 1993;68:101-3)

Fanconi's anaemia is an autosomal recessive condition that characteristically manifests as a cluster of congenital abnormalities, a progressive pancytopenia that becomes apparent during childhood, and a tendency to malignancy in later life. ${ }^{1}$ Wide variation in expression of the clinical features of Fanconi's anaemia has led to acceptance of hypersensitivity to the clastogenic

\begin{abstract}
Department of Pediatrics, King Faisal Specialist Hospital and Research Centre, PO Box 3354 Riyadh, Saudi Arabia R D G Milner

Abstract

A family in which three siblings born to related parents all manifested clinical abnormalities characteristic of Fanconi's anaemia (microcephaly, short stature, slow growth, beak nose, micrognathia, skin dyspigmentation and forearm and thumb dysplasia in $2 / 3$ ) is reported. All five family members had normal spontaneous chromosome breakage, a normal response to diepoxybutane and mitomycin $C$, and were fully informative for linkage with four DNA markers from chromosome 20q12-13.3 with no evidence for linkage. It is concluded that abnormalities typical for Fanconi's anaemia are inherited as an autosomal recessive without the defect responsible for increased chromosomal fragility and independently from the genes so far identified as being responsible for Fanconi's anaemia.
\end{abstract}

Polyclinic,
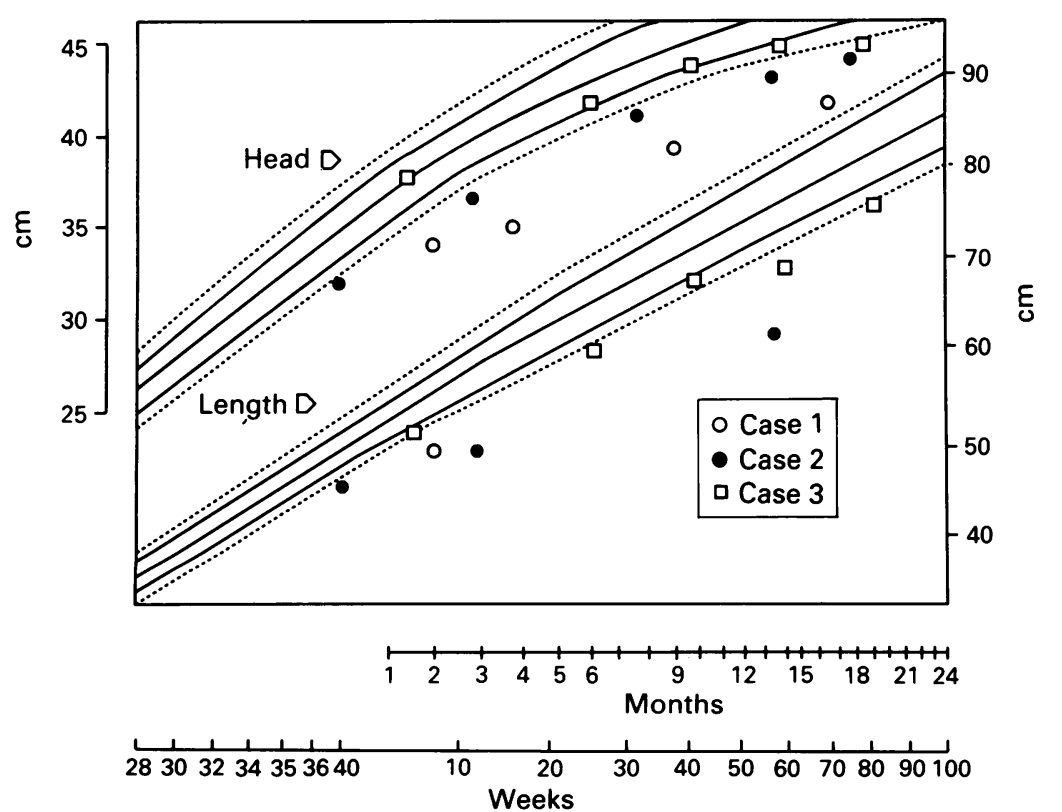

Figure 1 Growth in length and head circumference during the first two years plotted on a centile chart for girls. The boy is plotted according to the centiles, not absolute measurement. The 3rd, 10th, 50th, 90th, and 97th centiles are shown. effects of diepoxybutane as the unique diagnostic criterion of Fanconi's anaemia. ${ }^{2}$ When the diepoxybutane test was used as the absolute diagnostic discriminant, analysis of 162 patients with Fanconi's anaemia showed that the clinical variables most characteristic of Fanconi's anaemia were: microphthalmia, birth marks, kidney and urinary abnormalities, growth retardation, learning disability, absence of radius and other skeletal abnormalities. The diepoxybutane test is used to identify the rare patient with Fanconi's anaemia with no congenital clinical abnormality and to exclude sporadic cases with a clinical phenotype suggesting Fanconi's anaemia. Recent work has assigned a Fanconi's anaemia gene or genes to chromosome 20q by linkage analysis ( $\mathrm{R}$ Gibson et al, unpublished observations). ${ }^{3}$ To our knowledge there is no report of the clinical congenital anomalies characteristic of Fanconi's anaemia being inherited independently of the cellular defects that cause increased chromosomal fragility and pancytopenia. We report here a family in which three children born to second cousin parents all manifested clinical features typical for Fanconi's anaemia but who had no cellular or genetic abnormality diagnostic of Fanconi's anaemia.

\section{Case reports}

The parents were clinically normal second cousins of Palestinian origin. Paternal height was $178 \mathrm{~cm}$ and maternal height was $168 \mathrm{~cm}$. All three children were born at term weighing $3000-3200 \mathrm{~g}$ after a normal pregnancy. There was no history of failed pregnancy or similar clinical abnormalities in other family members.

CASE 1

The eldest child, a girl born in 1984 , developed normally apart from her physical abnormalities. She had microcephaly, was abnormally short from birth, and continued to grow slowly (fig 1). At age $7 \cdot 9$ she was $113 \mathrm{~cm}$ tall $(-2 \cdot 1 \mathrm{SD})$ and had a head circumference of $48 \mathrm{~cm}(-3 \cdot 0$ SD). She had a raindrop hypopigmented rash over the legs, arms and lower trunk, a small beak nose, micrognathia, small external ears (fig 2 ), and dysplastic thumbs (fig 3). Radiological examination of the skeleton revealed dysplasia of the elbows with underdevelopment of the proximal ulna and bilateral dislocation of the radial head. There was no definite skeletal abnormality of the thumb. The thoracic cage, spine, pelvis, and lower limbs were radiologically normal. Mental development was normal. 

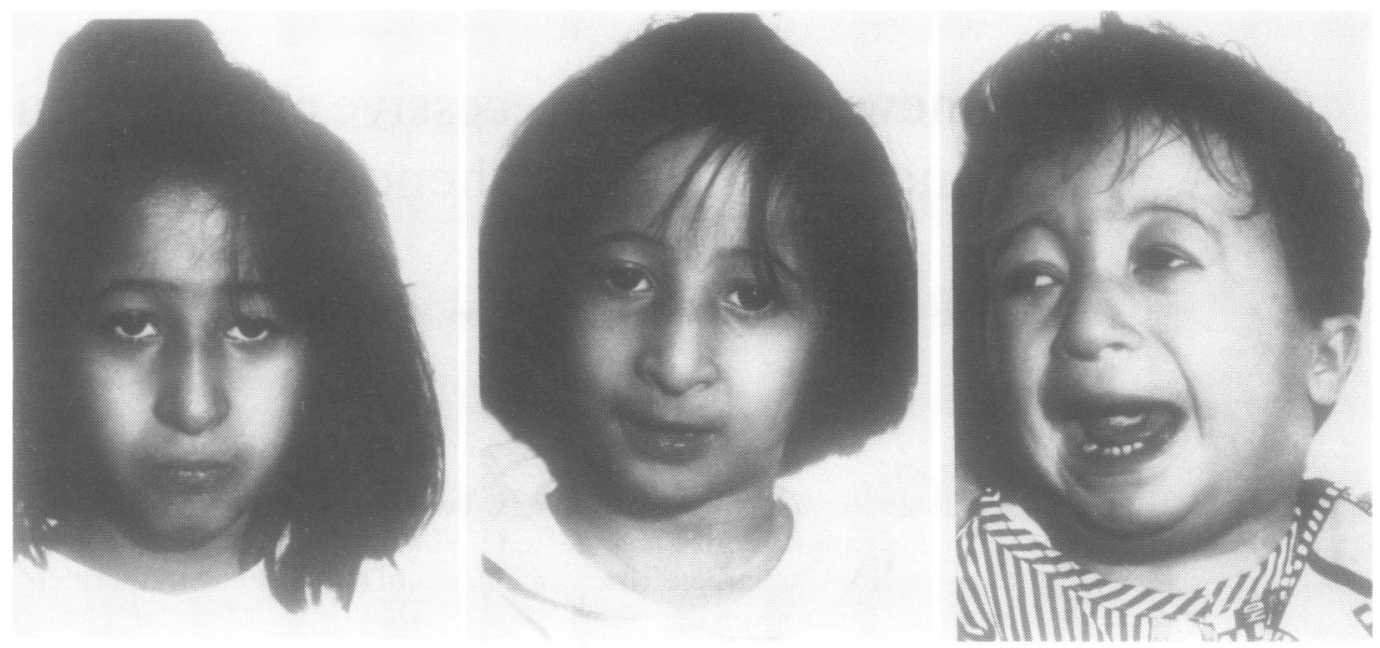

Figure 2 Facial appearances of the three siblings in order of age.

Chromosome analysis was normal female (46XX). When last seen (November 1991) haematology results were normal: haemoglobin concentration $120 \mathrm{~g} / \mathrm{l}$, white cell count $6.4 \times 10^{9} / 1$ with normal differential, and platelet count $286 \times 10^{9} / 1$.

\section{CASE 2}

The second child, a girl born in 1986, was immediately noted to resemble her sister in short stature and microcephaly, facial features, skeletal abnormalities, and skin rash. As she grew both her lack of height gain and her microcephaly were more severe than in her older sister (fig 1). At the age of 5.4 years her head circumference was $46 \mathrm{~cm}(-4 \cdot 2 \mathrm{SD})$ and her height was $93 \mathrm{~cm}(-3.5 \mathrm{SD})$. A skeletal survey revealed dysplasia of both elbow joints with dislocation of the right radial head and bilateral hypoplasia of both first metacarpals and phalanges. The thoracic cage, spine, pelvis, and lower limbs were radiologically normal. Mental development was normal. Chromosome analysis was normal female $(46 \mathrm{XX})$. When last seen (November 1991) haematology results were
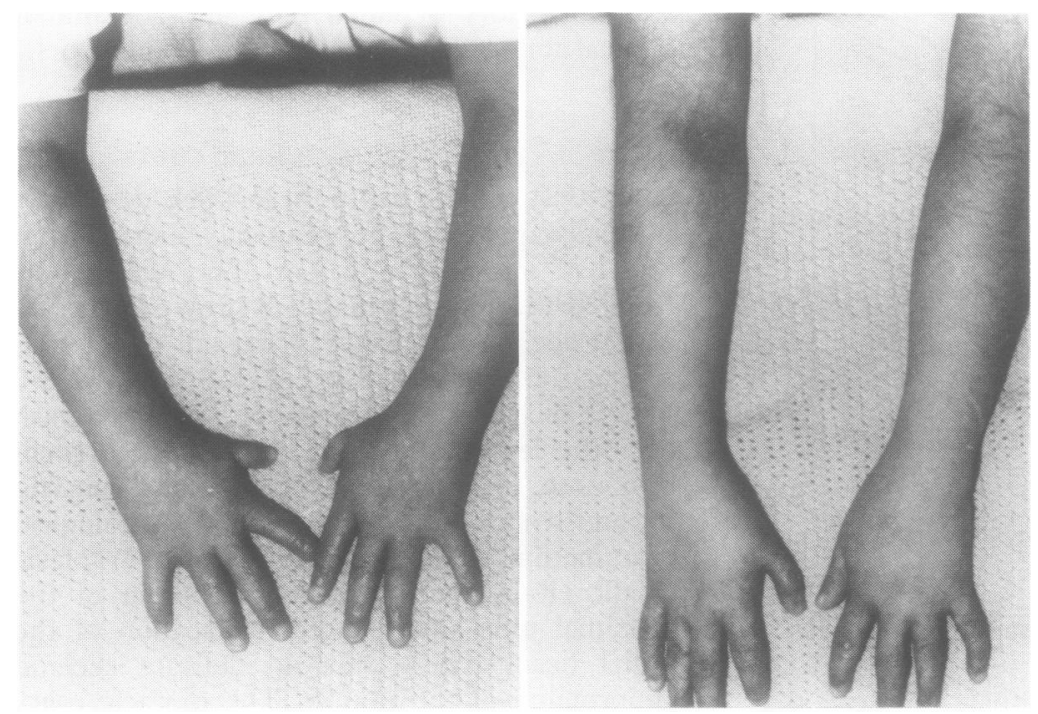

Figure 3 Forearms of the two sisters showing thumb dysplasia and raindrop hypopigmentation. The elder sister (case l) is on the left. normal: haemoglobin concentration $119 \mathrm{~g} / \mathrm{l}$, white cell count $12 \cdot 0 \times 10^{y} / 1$ with normal differential, and platelet count $310 \times 10^{9} / 1$.

CASE 3

The youngest child, a boy born in 1990, was the least severely affected. His length and head circumference were originally within normal limits (fig 1) but he crossed centiles downwards and at the age of 1.6 years his height was $78 \mathrm{~cm}$ $(-2.3 \mathrm{SD})$ and his head circumference is $46 \mathrm{~cm}$ $(-1.9 \mathrm{SD}) . \mathrm{He}$ resembled his sisters facially (fig 2) and also had the raindrop hypopigmentation of the trunk. The only radiological skeletal abnormality was genu vara. Mental and behavioural milestones were within normal limits. Chromosome analysis was normal male (46XY). When last seen (November 1991) haematology results showed an iron deficiency anaemia: haemoglobin concentration $98 \mathrm{~g} / \mathrm{l}$ with hypochromia and anisocytosis of the red cells, white cell count $17 \cdot 6 \times 10^{9} / 1$ with normal differential, and platelet count $271 \times 10^{9} / 1$.

There was no clinical evidence of cardiac or renal anomaly in any of the siblings.

\section{LABORATORY INVESTIGATIONS}

Phytohaemagglutinin stimulated lymphocyte cultures from all family members were exposed to either diepoxybutane at a final concentration of $0.1 \mu \mathrm{g} / \mathrm{ml}$ or mitomycin C at $0.03 \mu \mathrm{g} / \mathrm{ml} 24$ hours after initiation of the cultures. Breakage analysis was performed on 50-100 Giemsa stained metaphases from drug treated and untreated cultures. None of the family had chromosome abnormalities or a significant increase in either spontaneous chromosome breakage or sensitivity to diepoxybutane or mitonycin $\mathrm{C}$ (table).

Family members were typed with four linked multiallelic DNA markers spanning a 65 centimorgan interval from chromosome 20q 1213.3. Details of the markers and the genetic map are given in Grzeschik and Skolnick. ${ }^{4}$ The family was fully informative for linkage analysis and no evidence of linkage was found (fig 4). 
Response of phytohaemagglutinin stimulated lymphocyte cultures of diepoxybutane (DEB, $0 \cdot 1 \mu \mathrm{g} / \mathrm{ml})$ or mitomycin $C(M M C, 0.03 \mu \mathrm{g} / \mathrm{ml})$ in a family where three siblings have clinical features of Fanconi's anaemia

\begin{tabular}{|c|c|c|c|c|c|}
\hline Subject & Dose & $\begin{array}{l}\text { Cells } \\
\text { analysed }\end{array}$ & $\begin{array}{l}\text { Percentage } \\
\text { aberrant cells }\end{array}$ & Breaks/cell & $\begin{array}{l}\text { Breaks/ } \\
\text { aberrant cell }\end{array}$ \\
\hline Case 1 & $\begin{array}{l}\text { Nil } \\
\text { DEB } \\
\text { MMC }\end{array}$ & $\begin{array}{l}25 \\
50 \\
50\end{array}$ & $\begin{array}{r}4 \\
22 \\
20\end{array}$ & $\begin{array}{l}0 \cdot 0 \\
0 \cdot 06 \\
0 \cdot 14\end{array}$ & $\begin{array}{l}0 \cdot 0 \\
0 \cdot 27 \\
0.7\end{array}$ \\
\hline Case 2 & $\begin{array}{l}\text { Nil } \\
\text { DEB } \\
\text { MMC }\end{array}$ & $\begin{array}{l}25 \\
50 \\
50\end{array}$ & $\begin{array}{l}28 \\
22 \\
48\end{array}$ & $\begin{array}{l}0 \cdot 12 \\
0 \cdot 18 \\
0.36\end{array}$ & $\begin{array}{l}0.42 \\
0.8 \\
0.7\end{array}$ \\
\hline Case 3 & $\begin{array}{l}\text { Nil } \\
\text { DEB } \\
\text { MMC }\end{array}$ & $\begin{array}{l}50 \\
86 \\
50\end{array}$ & $\begin{array}{l}10 \\
29 \\
14\end{array}$ & $\begin{array}{l}0 \cdot 02 \\
0 \cdot 18 \\
0 \cdot 14\end{array}$ & $\begin{array}{l}0.2 \\
0.64 \\
1.0\end{array}$ \\
\hline Mother & $\begin{array}{l}\text { Nil } \\
\text { DEB } \\
\text { MMC }\end{array}$ & $\begin{array}{l}25 \\
50 \\
50\end{array}$ & $\begin{array}{r}20 \\
6 \\
14\end{array}$ & $\begin{array}{l}0 \cdot 04 \\
0 \cdot 0 \\
0 \cdot 12\end{array}$ & $\begin{array}{l}0 \cdot 2 \\
0 \cdot 0 \\
0 \cdot 85\end{array}$ \\
\hline Father & $\begin{array}{l}\text { Nil } \\
\text { DEB } \\
\text { MMC }\end{array}$ & $\begin{array}{r}100 \\
50 \\
50\end{array}$ & $\begin{array}{l}31 \\
18 \\
20\end{array}$ & $\begin{array}{l}0.15 \\
0.06 \\
0.0\end{array}$ & $\begin{array}{l}0.5 \\
0.3 \\
0.0\end{array}$ \\
\hline Control & $\begin{array}{l}\text { Nil } \\
\text { DEB }\end{array}$ & $\begin{array}{l}50 \\
50\end{array}$ & $\begin{array}{l}28 \\
12\end{array}$ & $\begin{array}{l}0.08 \\
0.06\end{array}$ & $\begin{array}{l}0.3 \\
0.5\end{array}$ \\
\hline
\end{tabular}

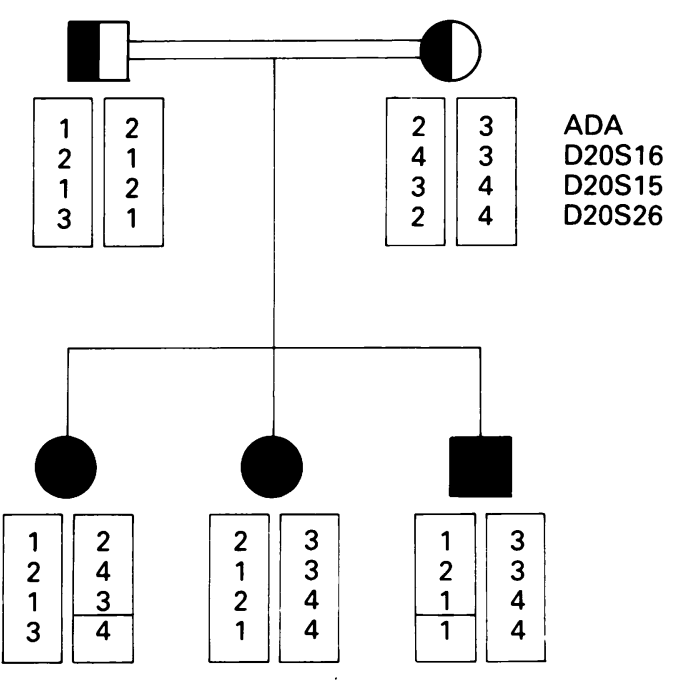

Figure 4 Family pedigree showing the results of linkage analysis using four markers for chromosome $20 q$.

\section{Discussion}

The first report of the International Fanconi Anaemia Registry emphasises the use of diepoxybutane as the unique discriminant for making a diagnosis of Fanconi's anaemia ${ }^{2}$ and illustrates the point with details of Fanconi's anaemia patients who have few or no clinical abnormalities and the prevalence of typical Fanconi anomalies in patients without Fanconi's anaemia. The inference is made that patients without Fanconi's anaemia with Fanconi clinical features occur sporadically. Our family provides convincing clinical evidence of a new autosomal recessive syndrome closely mimicking Fanconi's anaemia. The three siblings had clinical congenital abnormalities that are characteristic for Fanconi's anaemia, but are excluded from that diagnosis by the absence of chromosomal fragility and negative diepoxybutane test. The mode of inheritance and the clinical features seen in the family reported here are not compatible with any of the other syndromes listed in the differential diagnosis of Fanconi's anaemia. They do not have the absent radius necessary for the diagnosis of thrombocytopenia-absent radius (TAR) syndrome, nor any haematological abnormality to suggest Diamond-Blackfan anaemia. The skin shows no evidence of atrophy or hyperkeratosis, excluding dyskeratosis congenita and the normal cardiovascular findings rule out the Holt-Oram syndrome.

1 Gordon-Smith EC, Rutherford TR. Fanconi anaemiaconstitutional, familial, aplastic anaemia. Balliere's Clin Haematol 1989;2:139-52.

2 Auerbach AD, Rogatko A, Schroeder-Kurth TM. International Fanconi anemia registry: first report. In Schroeder-Kurth TM, Auerbach AD, Obe G, eds. Fancon anemia, clinical, cytogenetic and experimental aspects. Berlin: anemia, clinical, cytogenetic

3 Mann WR, Venkatraj VS, Allen RG, et al. Fanconi anemia: evidence for linkage heterogeneity on chromosome $20 \mathrm{q}$ Genomics 1991;9:329-37.

4 Grzeschik KH, Skolnick MH. Report of the committee on the genetic constitution of chromosome 20. Cytogenet Cell Genet (in press). 